\title{
Efficacy of boceprevir, an NS3 protease inhibitor, in combination with peginterferon alfa- $2 b$ and ribavirin in treatment-naive patients with genotype 1 hepatitis $C$ infection (SPRINT-1): an open-label, randomised, multicentre phase 2 trial
}

\begin{abstract}
Paul Y Kwo, Eric Lawitz, Jonathan McCone, Eugene R Schiff, John M Vierling, David Pound, Mitchell N Davis, Joseph S Galati, Stuart C Gordon, Natarajan Ravendhran, Lorenzo Rossaro, Frank H Anderson, Ira M Jacobson, Raymond Rubin, Kenneth Koury, Lisa D Pedicone, Clifford A Brass, Eirum Chaudhri, Janice K Albrecht, on behalf of the SPRINT-1 investigators*
\end{abstract}

\section{Summary}

Background Peginterferon plus ribavirin achieves sustained virological response (SVR) in fewer than half of patients with genotype 1 chronic hepatitis $\mathrm{C}$ virus infection treated for 48 weeks. We tested the efficacy of boceprevir, an NS3 hepatitis $\mathrm{C}$ virus oral protease inhibitor, when added to peginterferon alfa- $2 \mathrm{~b}$ and ribavirin.

Methods In part 1 of this trial, undertaken in 67 sites in the USA, Canada, and Europe, 520 treatment-naive patients with genotype 1 hepatitis $C$ virus infection were randomly assigned to receive peginterferon alfa- $2 \mathrm{~b} 1.5 \mu \mathrm{g} / \mathrm{kg} \mathrm{plus}$ ribavirin 800-1400 mg daily for 48 weeks (PR48; n=104); peginterferon alfa-2b and ribavirin daily for 4 weeks, followed by peginterferon alfa-2b, ribavirin, and boceprevir $800 \mathrm{mg}$ three times a day for 24 weeks (PR4/PRB24; $\mathrm{n=103)}$ or 44 weeks (PR4/PRB44; $n=103$ ); or peginterferon alfa-2b, ribavirin, and boceprevir three times a day for 28 weeks (PRB28; $\mathrm{n}=107$ ) or 48 weeks (PRB48; $n=103)$. In part 2, 75 patients were randomly assigned to receive either $\mathrm{PRB} 48(\mathrm{n}=16)$ or low-dose ribavirin (400-1000 mg) plus peginterferon alfa-2b and boceprevir three times a day for 48 weeks (low-dose PRB48; n=59). Randomisation was by computer-generated code, and study personnel and patients were not masked to group assignment. The primary endpoint was SVR 24 weeks after treatment. Analysis was by intention to treat. This study is registered with ClinicalTrials.gov, number NCT00423670.

Findings Patients in all four boceprevir groups had higher rates of SVR than did the control group (58/107 [54\%, 95\% CI 44-64], p=0 013 for PRB28; 58/103 [56\%, 44-66], p=0 005 for PR4/PRB24; 69/103 [67\%, 57-76], p<0.0001 for PRB48; and 77/103 [75\%, 65-83], p<0.0001 for PR4/PRB44; vs 39/104 [38\%, 28-48] for PR48 control). Lowdose ribavirin was associated with a high rate of viral breakthrough (16/59 [27\%]), and a rate of relapse (six of 27 [22\%]) similar to control (12/51 [24\%]). Boceprevir-based groups had higher rates of anaemia (227/416 [55\%] vs 35/104 [34\%]) and dysgeusia (111/416 [27\%] vs nine of 104 [9\%]) than did the control group.

Interpretation In patients with untreated genotype 1 chronic hepatitis $\mathrm{C}$ infection, the addition of the direct-acting antiviral agent boceprevir to standard treatment with peginterferon and ribavirin after a 4-week lead-in seems to have the potential to double the sustained response rate compared with that recorded with standard treatment alone.

Funding Merck.

\section{Introduction}

Chronic hepatitis $\mathrm{C}$ virus affects about 170 million people worldwide. Cirrhosis induced by hepatitis $\mathrm{C}$ virus is the most common indication for liver transplantation and is a major contributor to the worldwide increase in the incidence of hepatocellular cancer. ${ }^{1,2}$ Standard-of-care treatment of genotype 1 hepatitis $\mathrm{C}$ virus is pegylated interferon and ribavirin for 48 weeks, which results in sustained virological response (SVR) in about $40-50 \%$ of individuals. ${ }^{3-5}$ SVR rates for black patients treated with standard of care are substantially lower; in two studies undertaken almost exclusively in genotype 1 individuals, $19-28 \%$ of black people achieved SVR versus $52 \%$ of non-Hispanic white people. ${ }^{6,7}$ Those who achieve SVR can have long-term benefits with improvement in degrees of liver fibrosis, reduction in complications of chronic liver disease, and improved quality of life. Studies have shown that response-guided therapy can allow tailoring of duration of treatment, with week 4 viral clearance (rapid virological response) allowing shorter duration of therapy than for those who clear virus at week 12 (complete early virological response). ${ }^{9-12}$

Up until now, treatment for this disease has consisted of therapies to stimulate the immune system and interfere in a non-specific manner with viral replication. Research has focussed on therapies that inhibit hepatitis $\mathrm{C}$ virus proteins that are essential for intracellular replication; these drugs are referred to as direct-acting antiviral agents. ${ }^{13}$ Boceprevir
Lancet 2010; 376: 705-16 This online publication has been corrected. The corrected version first appeared at TheLancet.com on October 8, 2010 Published Online August 9, 2010 DOI:10.1016/S01406736(10)60934-8

See Comment page 662 ${ }^{*}$ Members listed at end of Article.

Department of Medicine, Division of Gastroenterology/ Hepatology, Indiana University School of Medicine, Indianapolis, IN, USA (PY Kwo MD); Alamo Medical Research, San Antonio, TX, USA (EJ Lawitz MD); Mount Vernon Endoscopy Center, Alexandria, VA, USA (J McCone MD); Divison of Hepatology, University of Miami, Miami, FL, USA (Prof E R Schiff MD); Departments of Medicine and Surgery, Baylor College of Medicine, Houston, TX, USA (Prof) M Vierling MD); Indianapolis Gastroenterology Research Foundation, Indianapolis, IN, USA (D Pound MD); Digestive CARESouth Florida Center of Gastroenterology, Wellington, FL, USA (M N Davis DO); Liver Specialists of Texas, Houston, TX, USA (J S Galati MD); Henry Ford Hospital, Detroit, MI, USA (S C Gordon MD); Department of Gastroenterology and Liver Disease, St Agnes Hospital Baltimore, MD, USA (N Ravendhran MD); Department of Internal Medicine, University of California-Davis Medical Center, Sacramento, CA, USA 
(Prof L Rossaro MD); Liver and Intestinal Research Centre, Vancouver, BC, Canada (F H Anderson MD); Weill Cornell Medical College, New York, NY, USA (Prof I M Jacobson MD); Liver Center of Atlanta, Atlanta, GA, USA (R Rubin MD); and Merck Kenilworth, NJ, USA (K Koury PhD, L D Pedicone PhD, CA Brass MD, EChaudhri MD, J K Albrecht PhD) Correspondence to: Dr Paul Y Kwo, Department of Medicine, Division of Gastroenterology/Hepatology, Indiana University School of Medicine, 975 West Walnut Street, Indianapolis, IN 46202-5121, USA pkwo@iupui.edu is a novel peptidomimetic NS3 protease inhibitor that forms a covalent reversible complex with the NS3 protease in vitro and has shown potent antiviral activity in the hepatitis $\mathrm{C}$ virus replicon system, and in patients who previously showed no response to peginterferon administered with or without ribavirin..$^{14,15}$ In a doseascending study in null responders ${ }^{16}$ boceprevir, when given in combination with peginterferon alfa- $2 \mathrm{~b}$ and ribavirin, was associated with a modest incremental haemoglobin reduction, as has been recorded with other direct-acting antiviral agents in the NS3 inhibitor class..$^{17,18}$ The NS3 protease inhibitor telaprevir has also shown significantly higher rates of SVR than has standard of care in patients with genotype 1 disease when given for 12 weeks in combination with regimens of peginterferon and ribavirin lasting 12,24 , or 48 weeks. ${ }^{17,18}$ Although rates of SVR in the telaprevir groups were higher than were those recorded with standard of care, investigators noted higher drop-out rates due to increased side-effects.

The aim of the hepatitis C virus SPRINT-1 (Serine Protease Inhibitor Therapy-1) study was to establish the safety and efficacy of boceprevir when added to peginterferon and ribavirin. We investigated treatment durations of 28 weeks versus 48 weeks, with and without a 4-week lead-in of peginterferon alfa- $2 \mathrm{~b}$ and ribavirin before the addition of boceprevir for 24 or 44 weeks, and the efficacy of low-dose ribavirin. The rationale for the 4-week lead-in was to allow pegylated interferon and ribavirin to reach steady-state concentrations before the addition of boceprevir such that backbone drug concentrations would be at an optimum and potentially reduce the likelihood for emergence of drug-resistant mutations by reducing viral levels. ${ }^{19-21}$ Part 2 of this study, which was added after enrolment in part 1 was completed, was undertaken to assess the possibility of use of a lower dose of ribavirin to reduce treatment complications, mainly anaemia. Since boceprevir and other NS3 protease inhibitors have been associated with a modest reduction in haemoglobin, weight-based low-dose (400-1000 mg per day) versus standard-dose (800-1400 mg per day) ribavirin was assessed to establish whether efficacy could be maintained while reducing anaemia. Lastly, we examined the rates of viral clearance and SVR.

\section{Methods \\ Study design and participants}

This was an open-label, randomised trial undertaken in hospitals in the USA, Canada, and Europe. Study enrolment began in January, 2007, and data collection concluded in November, 2008. Covance Central Laboratory Services in both Indianapolis, IN, USA, and Meyrin Geneva, Switzerland, were used as the contracted central laboratories for this study. Previously untreated adults with genotype 1 hepatitis $C$ virus infection, aged 18-60 years were eligible to be enrolled. Liver biopsy consistent with chronic hepatitis $\mathrm{C}$ virus infection within 5 years of enrolment was required. Minimum haematological and biochemical parameters included haemoglobin of $130 \mathrm{~g} / \mathrm{L}$ in men and $120 \mathrm{~g} / \mathrm{L}$ in women, neutrophil count $1.5 \times 10^{9} / \mathrm{L}$, platelet count $100 \times 10^{9} / \mathrm{L}$, and bilirubin, albumin, and creatinine within normal limits. Patients with a documented history of any of the following were excluded: decompensated cirrhosis, HIV infection, previous organ transplantation, other causes of liver disease, pre-existing psychiatric disease, seizure disorder, cardiovascular disease, haemoglobinopathies, haemophilia, poorly controlled diabetes, and autoimmune disease.

Before the start of the study, the study protocol and informed consent form were reviewed and approved by an institutional review board or ethics committee. We obtained written informed consent from all patients before any study-related activity was done; the study was undertaken in accordance with provisions of the Declaration of Helsinki and Good Clinical Practice guidelines. A Data Review Advisory Board met twice a year to monitor the progress of the study and review safety data. The board was to provide recommendations for stopping the study and modifying its design according to the guidance provided in the protocol. The committee included at least three members not employed by the sponsor (including one outside statistician and the committee's chairperson), who were not involved in the conduct of the study. None of the sponsor committee members had voting privileges.

\section{Randomisation and masking}

For part 1 of the study, patients were randomly assigned to one of the five treatment groups in a 1:1:1:1:1 ratio. Randomised treatment assignment was stratified by race (black vs non-black, self-reported) and cirrhosis status (cirrhosis vs no cirrhosis, on the basis of local pathology results). The sponsor's biostatistics department provided a computer generated random code to the external Central Randomization Center (Covance IVRS, Princeton, NJ, USA) to implement the randomisation. Once a prospective participant was determined to be eligible for the study, the site called the centre to obtain a patient number and treatment assignment for the participant.

For part 2, participants were randomly assigned in a 1:4 ratio to the standard ribavirin dose group or the lower ribavirin dose group, respectively, and there was no stratification. Implementation procedures were the same as for part 1. Participants, those giving the interventions, those assessing outcomes, and those analysing the data were not masked to group assignment.

\section{Procedures}

The study had seven treatment groups, which were grouped into two parts (figure 1). Part 1 consisted of five treatment groups: one was a control group in which patients received peginterferon alfa- $2 \mathrm{~b} 1.5 \mu \mathrm{g} / \mathrm{kg}$ plus ribavirin 800-1400 mg per day for 48 weeks (PR48). Two groups, the lead-in groups, received peginterferon alfa- $2 \mathrm{~b}$ $1.5 \mu \mathrm{g} / \mathrm{kg}$ and ribavirin 800-1400 mg daily for 4 weeks 
(PR4), followed by peginterferon alfa-2b, ribavirin, and boceprevir $800 \mathrm{mg}$ three times a day for 24 weeks (PRB24) or 44 weeks (PRB44). The last two groups of part 1 received peginterferon alfa-2b $1.5 \mu \mathrm{g} / \mathrm{kg}$, ribavirin 800-1400 mg, and boceprevir $800 \mathrm{mg}$ three times a day for 28 weeks (PRB28) or 48 weeks (PRB48). Part 2, in which participants were enrolled separately, consisted of two groups: one received PRB48 and served as a control for the last group, which explored the safety and efficacy of low-dose ribavirin (400-1000 mg) plus peginterferon alfa- $2 \mathrm{~b} 1.5 \mu \mathrm{g} / \mathrm{kg}$ and boceprevir $800 \mathrm{mg}$ three times a day for 48 weeks (low-dose PRB48).

The dosing for ribavirin was weight based: patients weighing $65 \mathrm{~kg}$ and less received $800 \mathrm{mg}$ per day $(400 \mathrm{mg}$ twice daily), those weighing 66-80 kg received $1000 \mathrm{mg}$ per day (400 $\mathrm{mg}$ in the morning and 600 in the evening), those weighing 81-105 $\mathrm{kg}$ received $1200 \mathrm{mg}$ per day (600 mg twice daily), and those weighing more than $105 \mathrm{~kg}$ received $1400 \mathrm{mg}$ per day (600 $\mathrm{mg}$ in the morning and 800 in the evening).

Adverse events were graded as mild, moderate, and severe or potentially life-threatening. Dependent on the severity of an adverse event that was deemed by the investigator to be related to peginterferon alfa-2b, the drug could be discontinued permanently, held for up to 2 weeks, or dose-reduced with a two-step reduction from $1.5 \mu \mathrm{g} / \mathrm{kg}$ to $1.0 \mu \mathrm{g} / \mathrm{kg}$, and then to $0.5 \mu \mathrm{g} / \mathrm{kg}$. For anaemia, the ribavirin dose was lowered by $200 \mathrm{mg}$ per day apart from in the $1400 \mathrm{mg}$ group when the initial reduction was $400 \mathrm{mg}$ per day. Dose reduction of boceprevir was by $200 \mathrm{mg}$ per dose to $600 \mathrm{mg}$ three times a day, and again to $400 \mathrm{mg}$ three times a day at the discretion of the investigator. Anaemia, defined as haemoglobin less than $100 \mathrm{~g} / \mathrm{L}$, was managed with protocol-recommended guidelines for ribavirin dose reduction. At the discretion of the investigator, use of epoetin alfa was allowed with concomitant ribavirin dose reduction.

The primary efficacy endpoint was SVR, defined as the proportion of patients with undetectable hepatitis $\mathrm{C}$ virus RNA (Roche Cobas TaqMan with lower limit of detection of $15 \mathrm{IU} / \mathrm{mL}$ ) 24 weeks after discontinuation of therapy. Genotype was measured with the TruGene assay (Bayer HealthCare, Berkeley, CA, USA). Viral breakthrough was defined as a $2 \log _{10}$ increase of hepatitis $C$ virus RNA from nadir detected on two consecutive measurements with a quantitative concentration of $50000 \mathrm{IU} / \mathrm{mL}$ or more. Mutations were assessed by population sequencing of the NS3 domain.

\section{Statistical analysis}

All inferential efficacy analyses were based on patients randomly assigned and treated in groups 1-5 in part 1 of the study. With 80 patients in each group, the study had $80 \%$ power to detect a $22 \%$ difference in SVR between the control group and any of the four boceprevir groups $(\alpha=0 \cdot 05$, two-sided test), assuming an SVR rate for control of $50 \%$ (ie, $72 \%$ vs $50 \%$ ). Part 2, which included a different cohort of patients from selected sites who were enrolled later and were assigned to drug treatment with a separate randomisation schedule, was designed to assess the PRB48 low-dose ribavirin regimen.

The primary statistical analysis for the primary endpoint was done with the Cochran-Mantel Haenszel $\chi^{2}$ test to compare the four boceprevir groups with control, adjusting for the baseline stratification factors, race (black vs non-black) and cirrhosis status (yes vs no). Since there were multiple treatment groups, a step-down approach was prespecified in the statistical hypothesis testing procedure to maintain the overall type- 1 error rate at $\alpha=0 \cdot 05$. First, PR4/PRB44 was compared with control with respect to SVR, and if this test was significant $(\mathrm{p}<0 \cdot 05)$, PRB48 was to be compared with control. If this comparison was also significant, PR4/PRB24 was to be compared with control, and if significant, PRB28 was to be compared with control. At any point, a non-significant result ( $\mathrm{p}>0 \cdot 05)$ would preclude further testing.

All assays to establish concentrations of hepatitis C virus RNA for all participants throughout the study were done in a masked manner by an independent commercial laboratory that did not have access to participant treatment assignments. The primary and other key study endpoints were based on concentration of hepatitis C virus RNA, which is an outcome that is not subject to bias.22

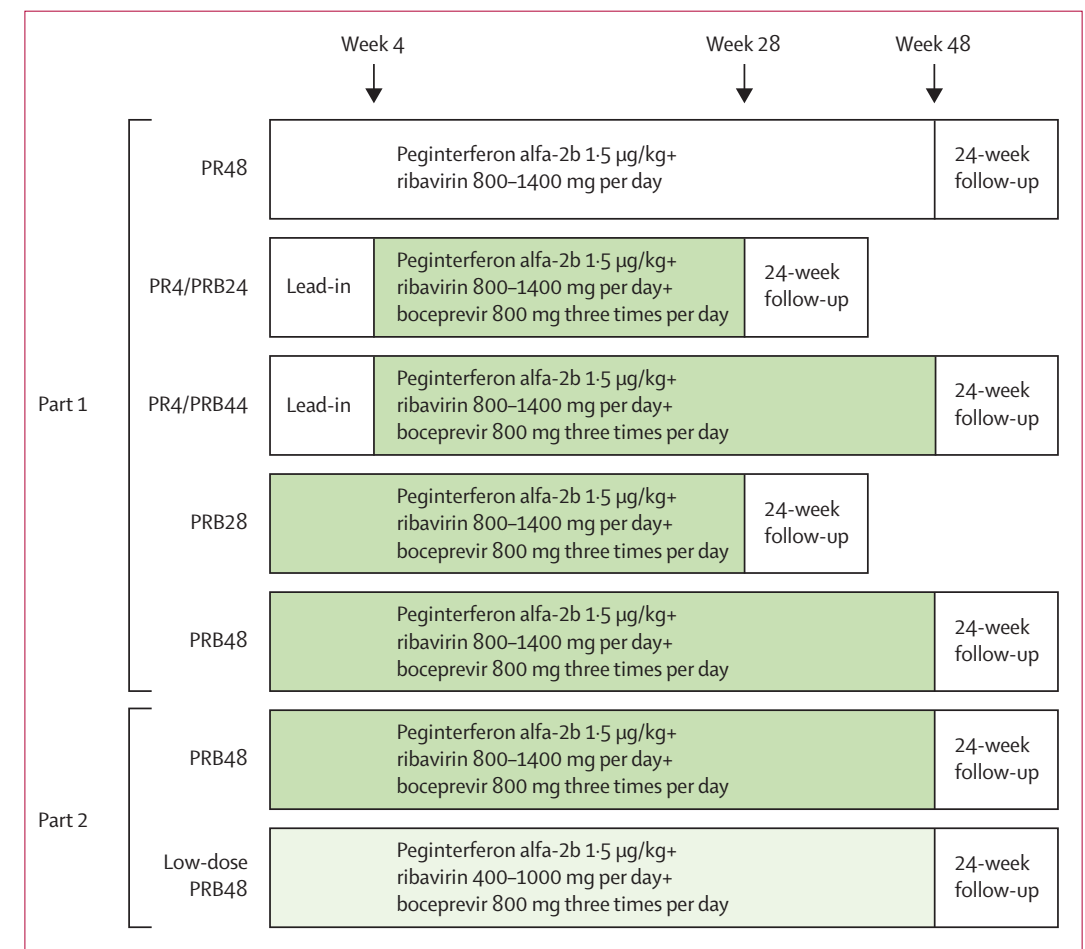

Figure 1: Trial design

Patients in all groups were followed up for 24 weeks after the end of treatment. PR4 (lead-in)=peginterferon alfa-2b $1.5 \mu \mathrm{g} / \mathrm{kg}$ plus ribavirin 800-1400 mg per day for 4 weeks. PR48 (control)=peginterferon alfa-2b $1.5 \mu \mathrm{g} / \mathrm{kg}$ plus ribavirin 800-1400 mg per day for 48 weeks. PRB24/28/44/48=peginterferon alfa-2b, ribavirin, and boceprevir $800 \mathrm{mg}$ three times a day for 24,28 , 44, or 48 weeks. Low-dose PRB48=peginterferon alfa-2b, ribavirin 400-1000 mg, and boceprevir $800 \mathrm{mg}$ three times a day for 48 weeks. 
Exact two-sided 95\% CIs for the SVR rate were calculated for each treatment group, whereas $95 \% \mathrm{CIs}$ for the difference between each boceprevir group (in part 1) and control (PR48 group) were based on a normal approximation. Nominal $\mathrm{p}$ values for each boceprevir group versus control were calculated for end of treatment $\left(\chi^{2}\right.$ test), SVR (Cochran-Mantel-Haenszel adjusted $\chi^{2}$ test), and viral breakthrough (Fisher's exact test).

To assess the effect of the 4-week lead-in on SVR, the pooled rate from the PRB28 and PRB48 groups was compared with the pooled rate from the PR4/PRB24 and PR4/PRB44 groups. Similarly, to assess the effect of treatment duration on SVR, the pooled rate from the 28-week groups was compared with the pooled rate from the 48-week groups.

The relation between rapid virological response, based on week 4 of boceprevir therapy (treatment week 8 in the groups with 4-week lead in) and SVR was summarised with the proportion of patients who achieved SVR in patients with concentrations of hepatitis $C$ virus RNA below the lower limit of detection at week 4 of boceprevir therapy. Similarly, the relation between viral clearance between weeks 4 and 12 of boceprevir (treatment weeks 8-16 in the lead-in groups) and SVR was summarised with the proportion of patients achieving SVR in those with concentrations of hepatitis $\mathrm{C}$ virus RNA below the lower limit of detection for the first time between weeks 4 and 12 of boceprevir therapy. Although comparisons among the treatment groups with respect to relapse rates were not randomised comparisons, nominal $\mathrm{p}$ values (based on two-sided $\chi^{2}$ tests) were calculated.

SVR was also summarised for important subpopulations of patients on the basis of prespecified baseline demographic and disease characteristics (identified in previous studies of patients with hepatitis $\mathrm{C}$ virus treated with peginterferon alfa-2b plus ribavirin). For each subpopulation, the odds ratio and $95 \% \mathrm{CI}$ for the treatment effect of PR4/PRB44 versus PR48 (control) was obtained from a logistic regression analysis of SVR on treatment, with adjustment for the stratification factors (race and cirrhosis status). Finally, data from the four boceprevir groups were combined, and a multivariable logistic regression analysis of SVR was done, with treatment and the baseline factors included as potential prognostic factors. A stepwise procedure was used to identify independent predictors of SVR (with $\mathrm{p}=0.05$ as the threshold for variables to be entered and retained in the final model).

Additionally, we examined the associations between the development of anaemia, use of epoetin alfa, and SVR. Since the rate of study discontinuation was fairly high, each boceprevir group was compared with control with respect to the discontinuation rate (two-sided $\chi^{2}$ test).

This trial is registered with ClinicalTrials.gov, number NCT00423670.

\begin{tabular}{|c|c|c|c|c|c|c|c|}
\hline & \multicolumn{5}{|l|}{ Part 1} & \multicolumn{2}{|l|}{ Part 2} \\
\hline & $\begin{array}{l}\text { PR48 } \\
(n=104)\end{array}$ & $\begin{array}{l}\text { PR4/PRB24 } \\
(n=103)\end{array}$ & $\begin{array}{l}\text { PR4/PRB44 } \\
(n=103)\end{array}$ & $\begin{array}{l}\text { PRB28 } \\
(n=107)\end{array}$ & $\begin{array}{l}\text { PRB48 } \\
(\mathrm{n}=103)\end{array}$ & $\begin{array}{l}\text { PRB48 } \\
(n=16)\end{array}$ & $\begin{array}{l}\text { Low-dose PRB48 } \\
(n=59)\end{array}$ \\
\hline \multicolumn{8}{|l|}{ Sex } \\
\hline Women & $34(33 \%)$ & $52(50 \%)$ & $45(44 \%)$ & 44 (41\%) & $40(39 \%)$ & $7(44 \%)$ & $18(31 \%)$ \\
\hline Men & $70(67 \%)$ & $51(50 \%)$ & $58(56 \%)$ & $63(59 \%)$ & $63(61 \%)$ & $9(56 \%)$ & $41(69 \%)$ \\
\hline \multicolumn{8}{|l|}{ Race } \\
\hline White & $83(80 \%)$ & $85(83 \%)$ & $85(83 \%)$ & $86(80 \%)$ & $87(84 \%)$ & $12(75 \%)$ & $43(73 \%)$ \\
\hline Non-white & $21(20 \%)$ & $18(17 \%)$ & $18(17 \%)$ & $21(20 \%)$ & $16(16 \%)$ & $4(25 \%)$ & $16(27 \%)$ \\
\hline American Indian or Alaskan & $2(2 \%)$ & $1(1 \%)$ & $1(1 \%)$ & 0 & 0 & 0 & 0 \\
\hline Asian & $3(3 \%)$ & $1(1 \%)$ & $2(2 \%)$ & $2(2 \%)$ & $1(1 \%)$ & 0 & 0 \\
\hline Black & $16(15 \%)$ & $15(15 \%)$ & $15(15 \%)$ & $18(17 \%)$ & $14(14 \%)$ & $4(25 \%)$ & $16(27 \%)$ \\
\hline Multiracial & 0 & $1(1 \%)$ & 0 & $1(1 \%)$ & $1(1 \%)$ & 0 & 0 \\
\hline Age (years) & $48 \cdot 3(6 \cdot 9)$ & $47 \cdot 7(7 \cdot 4)$ & $47 \cdot 6(8 \cdot 3)$ & $46 \cdot 4(8 \cdot 0)$ & $46 \cdot 7(8.8)$ & $50 \cdot 3(8 \cdot 5)$ & $48 \cdot 7(5 \cdot 8)$ \\
\hline Weight (kg) & $83 \cdot 4(16 \cdot 2)$ & $79 \cdot 9(14 \cdot 2)$ & $78 \cdot 4(16 \cdot 5)$ & $83 \cdot 4(17 \cdot 3)$ & $80 \cdot 0(19 \cdot 4)$ & $81 \cdot 4(12 \cdot 9)$ & $88.5(19.9)$ \\
\hline \multicolumn{8}{|l|}{ HCV genotype } \\
\hline $1 \mathrm{a}$ & $53(51 \%)$ & $53(51 \%)$ & $60(58 \%)$ & $67(63 \%)$ & $55(53 \%)$ & $7(44 \%)$ & $39(66 \%)$ \\
\hline $1 b$ & $42(40 \%)$ & $37(36 \%)$ & $35(34 \%)$ & $30(28 \%)$ & $36(35 \%)$ & $7(44 \%)$ & $18(31 \%)$ \\
\hline 1 (no subtype) & $9(9 \%)$ & $13(13 \%)$ & $8(8 \%)$ & $10(9 \%)$ & $12(12 \%)$ & $2(13 \%)$ & $2(3 \%)$ \\
\hline \multicolumn{8}{|l|}{ Baseline HCV RNA } \\
\hline $\log _{10}$ of geometric mean & $6 \cdot 53$ & $6 \cdot 53$ & $6 \cdot 53$ & $6 \cdot 64$ & $6 \cdot 54$ & $6 \cdot 43$ & $6 \cdot 47$ \\
\hline$>600000 \mathrm{IU} / \mathrm{mL}$ & $94(90 \%)$ & $90(87 \%)$ & $93(90 \%)$ & $98(92 \%)$ & $94(91 \%)$ & $13(81 \%)$ & $49(83 \%)$ \\
\hline Cirrhosis & $8(8 \%)$ & $7(7 \%)$ & $6(6 \%)$ & $7(7 \%)$ & $9(9 \%)$ & 0 & $4(7 \%)$ \\
\hline \multicolumn{8}{|c|}{$\begin{array}{l}\text { Data are number (\%) or mean (SD), unless otherwise indicated. PR4 (lead-in)=peginterferon alfa-2b } 1.5 \mu \mathrm{\mu g} / \mathrm{kg} \text { plus ribavirin 800- } 1400 \mathrm{mg} \text { per day for } 4 \text { weeks. } \\
\text { PR48 (control)=peginterferon alfa-2b } 1.5 \mu \mathrm{g} / \mathrm{kg} \text { plus ribavirin } 800-1400 \mathrm{mg} \text { per day for } 48 \text { weeks. PRB24/28/44/48=peginterferon alfa- } 2 \mathrm{~b} \text {, ribavirin, and boceprevir } 800 \mathrm{mg} \text { three } \\
\text { times a day for } 24,28,44 \text {, or } 48 \text { weeks. Low-dose PRB48=peginterferon alfa-2b, ribavirin } 400-1000 \mathrm{mg} \text {, and boceprevir } 800 \mathrm{mg} \text { three times a day for } 48 \text { weeks. HCV=hepatitis C virus. }\end{array}$} \\
\hline
\end{tabular}




\section{Role of the funding source}

The sponsor of the study contributed to patient recruitment, trial management, data collection, statistical analyses, and the writing and review of the report. The corresponding author had full access to all the data in the study and had final responsibility for the decision to submit for publication.

\section{Results}

765 patients were screened and 595 were enrolled in 43 US, four Canadian, and 20 European Union sites. All efficacy and safety analyses were based on 595 patients who were randomly assigned and received at least one dose of medication. Table 1 shows baseline characteristics, and figures 2 and 3 show patient disposition for all groups.

Table 2 shows virological response. Irrespective of treatment duration or use of PR4 as lead-in, SVR rates in all four boceprevir groups in part 1 were significantly better than were those in the PR48 control group. In the 28-week treatment groups, the SVR was 56\% (95\% CI 46-66) in the PR4/PRB24 group ( $\mathrm{p}=0.005$ vs control) and $54 \%$ (44-64) in the PRB28 group ( $\mathrm{p}=0.013$ vs control). In the 48 -week treatment groups, the SVR was 75\% (65-83) in the PR4/ PRB44 group ( $<<0.0001$ vs control) compared with $67 \%$ (57-76) in the PRB48 group ( $\mathrm{p}<0.0001$ vs control). In part 2 , the SVR for low-dose PRB48 was 36\% (24-49).

We noted significantly lower relapse rates in the 48-week treatment groups compared with PR48 control (PRB48, $\mathrm{p}=0 \cdot 0079 ; \mathrm{PR} 4 / \mathrm{PRB} 44, \mathrm{p}=0 \cdot 0002$; table 2). Although the relapse rates were higher in the 28 -week than in the 48-week treatment groups, patients in the 28-week groups who had rapid hepatitis $\mathrm{C}$ virus RNA clearance at week 4 of boceprevir had substantially lower relapse rates than did those who did not have rapid viral

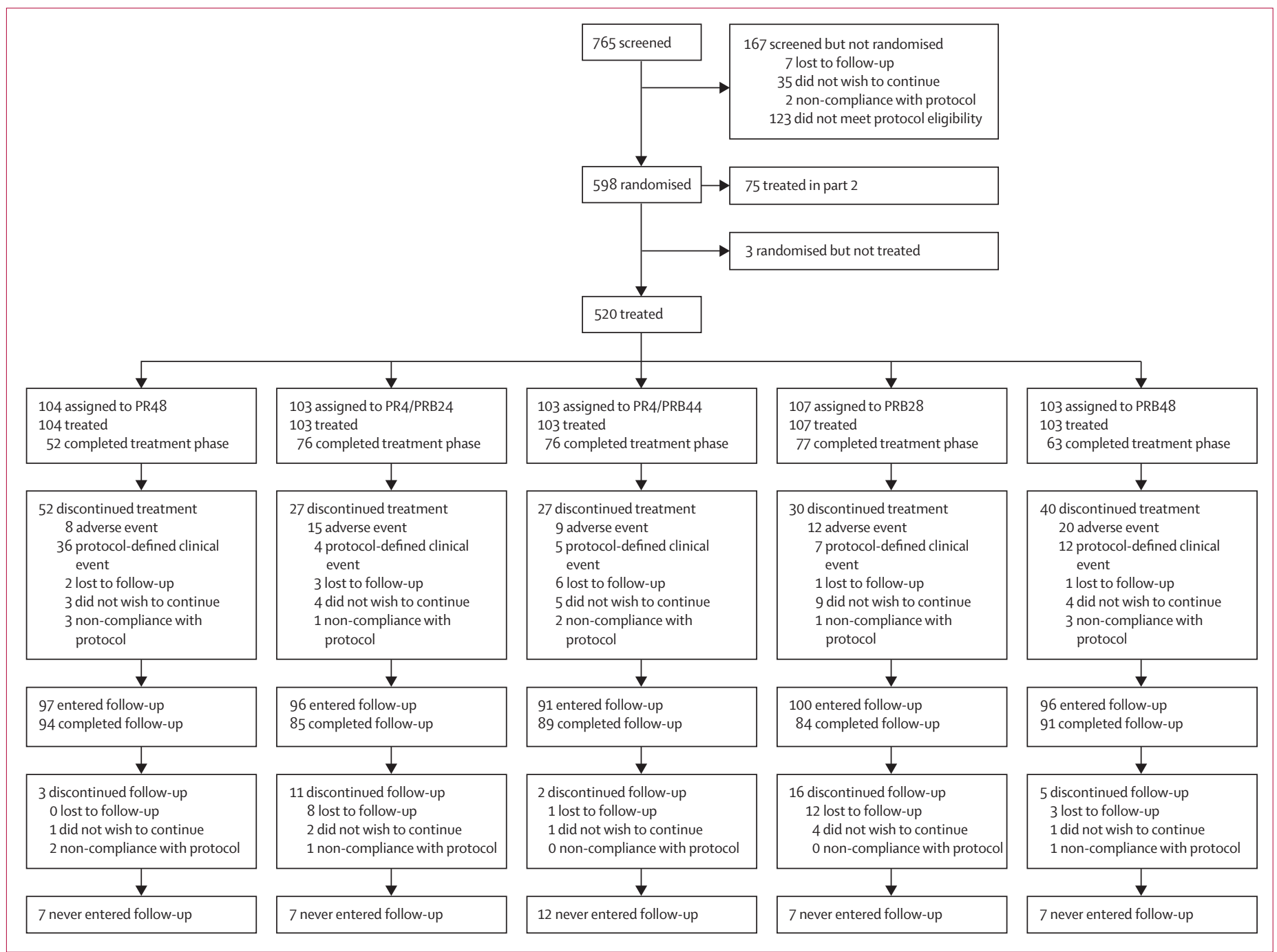

Figure 2: Trial profile for part 1 of the study

PR4 (lead-in)=peginterferon alfa- $2 \mathrm{~b} 1.5 \mathrm{\mu g} / \mathrm{kg}$ plus ribavirin $800-1400 \mathrm{mg}$ per day for 4 weeks. PR48 (control)=peginterferon alfa- $2 \mathrm{~b} 1.5 \mu \mathrm{g} / \mathrm{kg}$ plus ribavirin $800-1400 \mathrm{mg}$ per day for 48 weeks. PRB24/28/44/48=peginterferon alfa-2b, ribavirin, and boceprevir $800 \mathrm{mg}$ three times a day for 24,28 , 44 , or 48 weeks. 


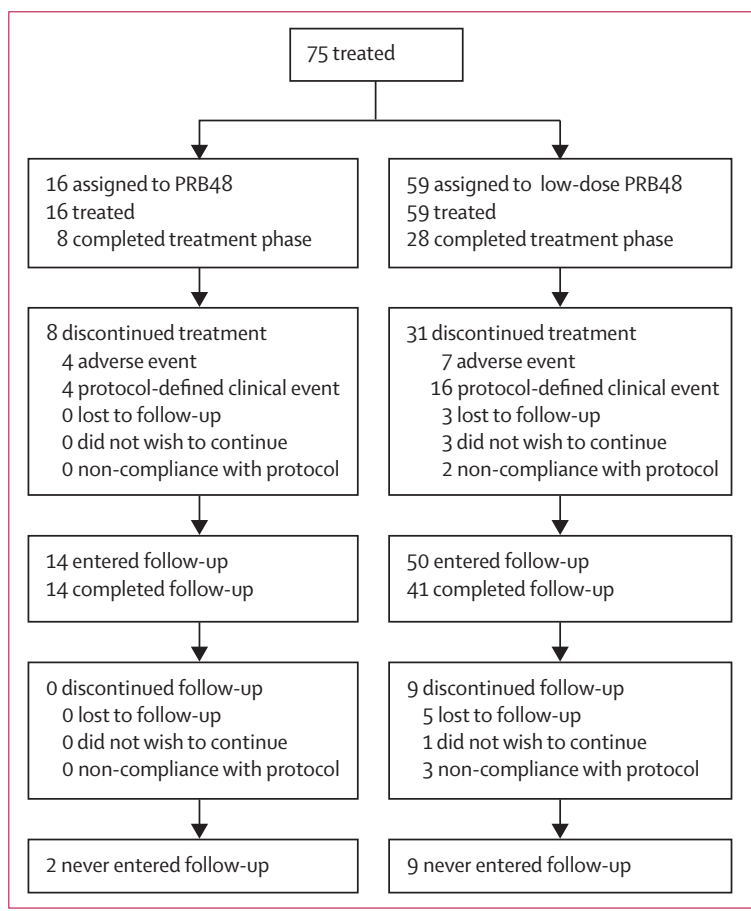

Figure 3: Trial profile for part 2 of the study

PRB48=peginterferon alfa-2b, ribavirin, and boceprevir $800 \mathrm{mg}$ three times a day for 48 weeks. Low-dose PRB48=peginterferon alfa- $2 b$, ribavirin 400-1000 mg, and boceprevir $800 \mathrm{mg}$ three times a day for 48 weeks.

clearance $(p<0 \cdot 0001 ;$ table 2$)$. Low-dose PRB was associated with high relapse rates. Of note, we recorded no viral breakthrough in control groups that did not contain boceprevir (table 2). In the boceprevir groups, the lead-in groups were associated with a modestly lower rate of breakthrough than were the groups with no lead in. Combining across treatment groups, the rate of breakthrough in the boceprevir lead-in groups was $4 \%$ (nine of 206) compared with $9 \%$ (19/210) in the boceprevir groups with no lead in $(\mathrm{p}=0 \cdot 057)$. By population sequencing, the major mutations (in $>25 \%$ of samples) were V36M, T54S, and R155K, with less common (in 5\% to $<25 \%$ ) mutations including T54A, V55A, R155T, A156S, V158I, and V170A (data not shown). Infrequent mutations (in $<5 \%$ of samples) included V36A, V36L, and I170T (data not shown).

Rapid virological response was highly associated with SVR in all treatment groups. In the 28-week treatment groups, $82 \%(54 / 66)$ of patients in the PR4/PRB24 group and $74 \%(32 / 43)$ in the PRB28 group who had rapid virological response achieved SVR. In the 48-week treatment groups, $94 \%(62 / 66)$ of patients assigned to PR4/PRB44 and 84\% (32/38) assigned to PRB48 who achieved undetectable hepatitis $C$ virus RNA by week 4 of boceprevir achieved SVR. Achievement of undetectable hepatitis C virus RNA between weeks 4 and 12 of boceprevir therapy was also highly predictive of SVR in the 48-week treatment groups (table 3; figure 4). We noted a greater SVR in patients who cleared virus between weeks 4 and 12 of boceprevir in the PR4/PRB44 group compared with the PR4/PRB24 group (table 3).

The lead-in (PR4) allowed us to examine the relation of peginterferon and ribavirin responsiveness at week 4 to SVR with boceprevir-containing regimens. In the PR4 28-week or 48-week groups, SVR was similar in participants with greater than $1.5 \log _{10}$ reduction in hepatitis $\mathrm{C}$ virus RNA from baseline before the addition of boceprevir. Higher SVR was noted in participants who received PRB for 44 weeks with less than $1.5 \log _{10}$ reduction from baseline at PR4 (figure 5). In patients

\begin{tabular}{|c|c|c|c|c|c|c|c|}
\hline & \multicolumn{5}{|l|}{ Part 1} & \multicolumn{2}{|l|}{ Part 2} \\
\hline & PR48 ( $n=104)$ & PR4/PRB24 (n=103) & PR4/PRB44 (n=103) & PRB28 (n=107) & PRB48 (n=103) & PRB48 $(n=16)$ & Low-dose PRB48 $(n=59)$ \\
\hline Overall SVR (\%; 95\% CI)* & $39(38 \% ; 28-48 \%)$ & $58(56 \% ; 46-66 \%)$ & $77(75 \% ; 65-83 \%)$ & $58(54 \% ; 44-64 \%)$ & $69(67 \% ; 57-76 \%)$ & $8(50 \% ; 25-75 \%)$ & $21(36 \% ; 24-49 \%)$ \\
\hline Difference from control ( $95 \% \mathrm{Cl})$ &.. & $19 \%(5-32) \dagger$ & $37 \%(25-50) \dagger$ & $17 \%(3-30) \ddagger$ & $29 \%(16-42) \dagger$ &.. &.. \\
\hline TW 4 & $8(8 \%)$ & $3(3 \%)$ & $9(9 \%)$ & $42(39 \%)$ & $38(37 \%)$ & $7(44 \%)$ & $15(25 \%)$ \\
\hline TW 8 & $22(21 \%)$ & $62(60 \%)$ & $66(64 \%)$ & $71(66 \%)$ & $64(62 \%)$ & $11(69 \%)$ & $24(41 \%)$ \\
\hline TW 12 & $35(34 \%)$ & $71(69 \%)$ & $79(77 \%)$ & $78(73 \%)$ & $70(68 \%)$ & $8(50 \%)$ & $32(54 \%)$ \\
\hline TW 24 & $54(52 \%)$ & $74(72 \%)$ & $82(80 \%)$ & $71(66 \%)$ & $71(69 \%)$ & $8(50 \%)$ & $28(48 \%)$ \\
\hline TW 48 & $48(46 \%)$ & NA & $73(71 \%)$ & NA & $60(58 \%)$ & $6(38 \%)$ & $25(42 \%)$ \\
\hline End of treatment $\S$ & $53(51 \%)$ & $79(77 \%) \dagger$ & $81(79 \%) \dagger$ & $84(79 \%) \dagger$ & $76(74 \%) \dagger$ & $9(56 \%)$ & $28(48 \%)$ \\
\hline Relapse rate $\mathbb{\top}$ & $12(24 \%)$ & $18(24 \%)$ & $2(3 \%) \dagger$ & $24(30 \%)$ & $5(7 \%) \dagger$ & $1(11 \%)$ & $6(22 \%)$ \\
\hline Viral breakthrough|| & 0 & $4(4 \%)$ & $5(5 \%)$ & $7(7 \%) \dagger$ & $12(12 \%) \dagger$ & $4(25 \%)$ & $16(27 \%)$ \\
\hline
\end{tabular}

Data are number (\%) unless otherwise indicated. PR4 (lead-in)=peginterferon alfa- $2 \mathrm{~b} 1.5 \mathrm{\mu g} / \mathrm{kg}$ plus ribavirin $800-1400 \mathrm{mg}$ per day for 4 weeks. PR48 (control)=peginterferon alfa- $2 \mathrm{~b} 1.5 \mu \mathrm{g} / \mathrm{kg}$ plus ribavirin 800-1400 mg per day for 48 weeks. PRB24/28/44/48=peginterferon alfa-2b, ribavirin, and boceprevir $800 \mathrm{mg}$ three times a day for $24,28,44$, or 48 weeks. Low-dose PRB48=peginterferon alfa-2b, ribavirin 400-1000 mg, and boceprevir $800 \mathrm{mg}$ three times a day for 48 weeks. SVR=sustained virological response. TW=treatment week. NA=not available. *Patients who discontinued therapy before the end of their specified duration were followed up, and those with undetectable hepatitis ( virus RNA at end of follow-up were counted as having achieved SVR. †Nominal $p$ values $<0.01$ (treatment vs control) for end of treatment, SVR, and relapse and viral breakthrough in part 1. $¥$ Nominal p values $<0.05$ (treatment vs control) for end of treatment, SVR, and relapse and viral breakthrough in part 1 . SLast dose of study drug TRelapse rate is defined as the proportion of patients with detectable hepatitis ( virus RNA at end of follow-up in patients who were undetectable at end of treatment and not missing follow-up data. Relapse rates in part 1 in those who cleared virus at week 4 of boceprevir therapy were $11 \%$ (95\% CI 5-22) for PR4/PRB24, 2\% (0-9) for PR4/PRB44, 21\% (9-36) for PRB28, and 6\% (1-20) for PRB48; and for part 2, $0 \%(0-46)$ for PRB48 and $14 \%$ (2-43) for low-dose PRB48. ||Persistent $\geq 2 \log _{10}$ increase from nadir and $\geq 50000 \mathrm{IU} / \mathrm{mL}$.

Table 2: Virological response 
with less than $1 \log _{10}$ reduction with PR4, 55\% (95\% CI 32-76) SVR was noted in the PR4/PRB44 group.

A multivariate regression analysis of pooled boceprevir groups in part 1 of the study was done by investigation of baseline factors associated with SVR. These factors included low viral load $(\leq 600000 \mathrm{IU} / \mathrm{mL})$, non-black race, lower platelet count, and genotype $1 \mathrm{~b}$. In the control group of this study which received the standard of care, black people and those with cirrhosis had a lower SVR than did participants of non-black race and with no cirrhosis (table 4). The SVR rate for black people in the PR48 control group was 13\% (two of 16) and as high as $53 \%$ (eight of 15 ) in patients treated with boceprevir for 48 weeks (table 4). In patients with cirrhosis, the SVR rate was $67 \%$ (ten of 15 ) in the combined longer duration boceprevir groups versus $25 \%$ (two of eight) in the control group; in patients without cirrhosis, the SVR rate for the combined longer duration boceprevir groups was $71 \%$ (136/191) compared with $39 \%(37 / 96)$ for the control group.

We also noted increased rates of SVR in patients who developed anaemia (haemoglobin $<100 \mathrm{~g} / \mathrm{L}$ ) irrespective of treatment group. Epoetin alfa was used by $40 \%$ $(236 / 595)$ of patients and was allowed at investigator discretion. The use of this drug in those with anaemia was also associated with an improved SVR (table 4).

The most common adverse events in the boceprevir groups, as reported by investigators, were fatigue, anaemia, nausea, and headache-a side-effect profile generally similar to that recorded in patients receiving PR48 control. The rate of dysgeusia and anaemia was higher in the boceprevir groups than in other groups (table 5). In the boceprevir groups, we detected nadir haemoglobin concentrations of $85-100 \mathrm{~g} / \mathrm{L}$ in those who developed anaemia; and haemoglobin concentrations less than $85 \mathrm{~g} / \mathrm{L}$ were rare (table 6). Dose modifications of ribavirin were similar in boceprevir groups compared with the PR48 control group, and boceprevir dose modifications were rare (table 7). We recorded an overall higher discontinuation rate in the boceprevir groups than in the control group (table 7). Treatment discontinuations attributable to adverse events ranged from $9 \%$ to $19 \%$ in the groups receiving boceprevir therapy compared with $8 \%$ for the PR48 group, with two patients discontinuing treatment because of anaemia in the boceprevir groups (table 7). The rate of adverse events categorised as skin and subcutaneous tissue disorders was similar in boceprevir-containing regimens (159/416, $38 \%)$ and the control group (38/104, 37\%).

\section{Discussion}

The results of this phase 2 trial have shown that an optimum dose of boceprevir (800 mg three times a day), when added to the standard of care for treatment of chronic genotype 1 hepatitis $\mathrm{C}$ virus, significantly increased SVR in both 28-week and 48-week regimens compared with the control of peginterferon alfa- $2 \mathrm{~b}$ and

\begin{tabular}{|c|c|c|c|c|c|}
\hline & $\begin{array}{l}\text { PR48 } \\
(n=104)\end{array}$ & $\begin{array}{l}\text { PR4/PRB24 } \\
(n=103)\end{array}$ & $\begin{array}{l}\text { PR4/PRB44 } \\
(n=103)\end{array}$ & $\begin{array}{l}\text { PRB28 } \\
(n=107)\end{array}$ & $\begin{array}{l}\text { PRB48 } \\
(n=103)\end{array}$ \\
\hline$\leq 4$ weeks* & $100 \%(8 / 8)$ & $82 \%(54 / 66)$ & $94 \%(62 / 66)$ & $74 \%(32 / 43)$ & $84 \%(32 / 38)$ \\
\hline$>4$ week $-\leq 12$ weeks* & $83 \%(24 / 29)$ & $21 \%(4 / 19)$ & $79 \%(15 / 19)$ & $62 \%(26 / 42)$ & $84 \%(36 / 43)$ \\
\hline$>12$ weeks* & $30 \%(7 / 23)$ & $0 \%(0 / 1)$ & $0 \%(0 / 1)$ & $0 \%(0 / 3)$ & $17 \%(1 / 6)$ \\
\hline Never undetectable & $0 \%(0 / 44)$ & $0 \%(0 / 17)$ & $0 \%(0 / 17)$ & $0 \%(0 / 19)$ & $0 \%(0 / 16)$ \\
\hline All participants & $38 \%(39 / 104)$ & $56 \%(58 / 103)$ & $75 \%(77 / 103)$ & $54 \%(58 / 107)$ & $67 \%(69 / 103)$ \\
\hline \multicolumn{6}{|c|}{$\begin{array}{l}\text { Data are } \%(\mathrm{n} / \mathrm{N}) \text {. PR4 (lead-in)=peginterferon alfa- } 2 \mathrm{~b} 1.5 \mu \mathrm{g} / \mathrm{kg} \text { plus ribavirin } 800-1400 \mathrm{mg} \text { per day for } 4 \text { weeks. } \\
\text { PR48 (control)=peginterferon alfa- } 2 \mathrm{~b} 1.5 \mathrm{\mu g} / \mathrm{kg} \text { plus ribavirin } 800-1400 \mathrm{mg} \text { per day for } 48 \text { weeks. } \\
\text { PRB24/28/44/48=peginterferon alfa- } 2 \mathrm{~b} \text {, ribavirin, and boceprevir } 800 \mathrm{mg} \text { three times a day for } 24,28,44 \text {, or } \\
48 \text { weeks. *Exposure to weeks of peginterferon alfa- } 2 \mathrm{~b} \text { and ribavirin for group } 1 \text { and to weeks of boceprevir for } \\
\text { groups 2-5. }\end{array}$} \\
\hline
\end{tabular}

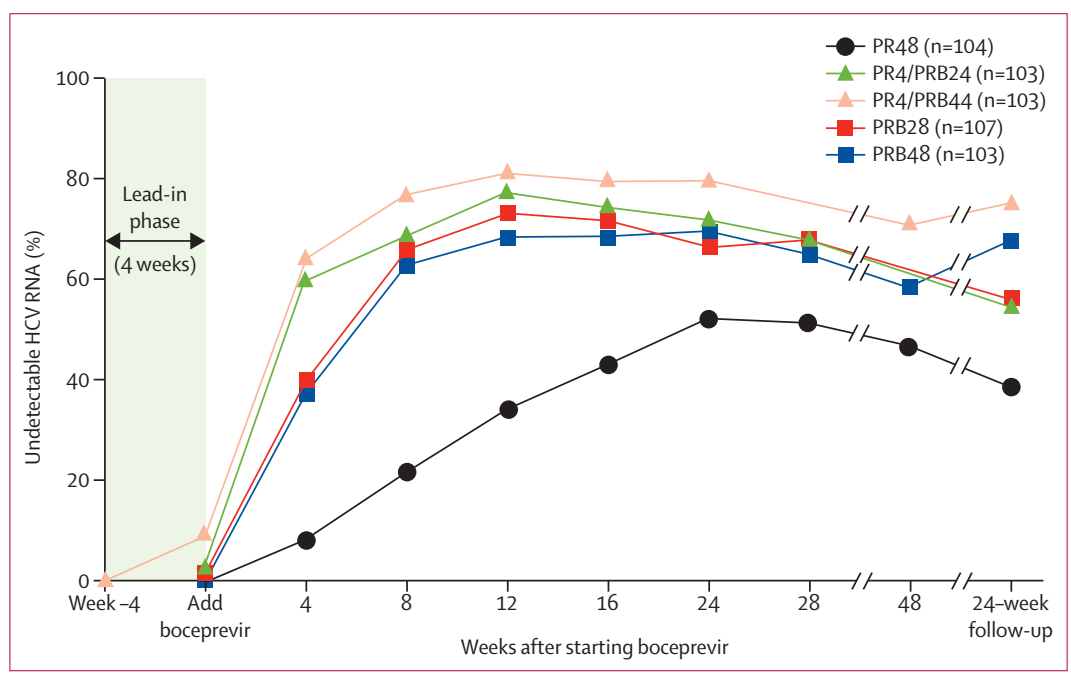

Figure 4: Percentage of patients with undetectable hepatitis C virus (HCV) RNA over time PR4 (lead-in)=peginterferon alfa-2b $1.5 \mu \mathrm{g} / \mathrm{kg}$ plus ribavirin $800-1400 \mathrm{mg}$ per day for 4 weeks. PR48 (control)=peginterferon alfa- $2 \mathrm{~b} 1.5 \mu \mathrm{g} / \mathrm{kg}$ plus ribavirin 800-1400 mg per day for 48 weeks. PRB24/28/44/48=peginterferon alfa-2b, ribavirin, and boceprevir $800 \mathrm{mg}$ three times a day for $24,28,44$, or 48 weeks.

ribavirin. Responses in the 48 -week boceprevir groups were substantially higher than were those in the 28 -week groups, with a near doubling of SVR in the PR4/PRB44 group. The use of low-dose ribavirin in combination with peginterferon and boceprevir, while reducing haematological toxic effects, did not improve SVR rates compared with control.

These results are consistent with those recorded in two trials of another NS3 protease inhibitor, telaprevir, in combination with peginterferon and ribavirin, in populations that excluded those with histological cirrhosis and had fewer black people. ${ }^{17,18}$ In one of these studies, ${ }^{17}$ undertaken in the USA, the SVR rate in the telaprevir group receiving 24 weeks of treatment with 12 weeks of telaprevir and 24 weeks of peginterferon and ribavirin was $20 \%$ higher than in the control group of 48 weeks of peginterferon and ribavirin (61\% [48/79] vs $41 \%$ [31/75]); and in the telaprevir group receiving 48 weeks of treatment with 12 weeks of telaprevir added to 48 weeks of peginterferon and ribavirin, the SVR rate 
was $26 \%$ higher than it was in the 48 -week control group $(67 \%[53 / 79]$ vs $41 \%[31 / 75])$. In the other study, ${ }^{18}$ undertaken in Europe, the SVR rate in the telaprevir group receiving 24 weeks of treatment with 12 weeks of telaprevir and 24 weeks of peginterferon and ribavirin was $23 \%$ higher than in the 48 -week control group $(69 \%$ [56/81] vs 46\% [38/82]). Although the study designs and populations differed, in our study, SVR rates were $17-19 \%$ higher than in the control group in the 28 -week boceprevir group, and 29-37\% higher than control in the 48 -week boceprevir groups.
In black participants and in those with cirrhosis, the addition of boceprevir to standard of care improved SVR. These preliminary results in a fairly small number of patients suggest that the addition of boceprevir to peginterferon alfa- $2 \mathrm{~b}$ and ribavirin will improve SVR in these difficult-to-treat populations.

This study assessed the use of a PR4 lead-in before the addition of boceprevir, as well as the effect of starting all three drugs concomitantly, and compared these groups with PR48 control. In the novel lead-in approach, we recorded increased SVR and a reduction in relapse and

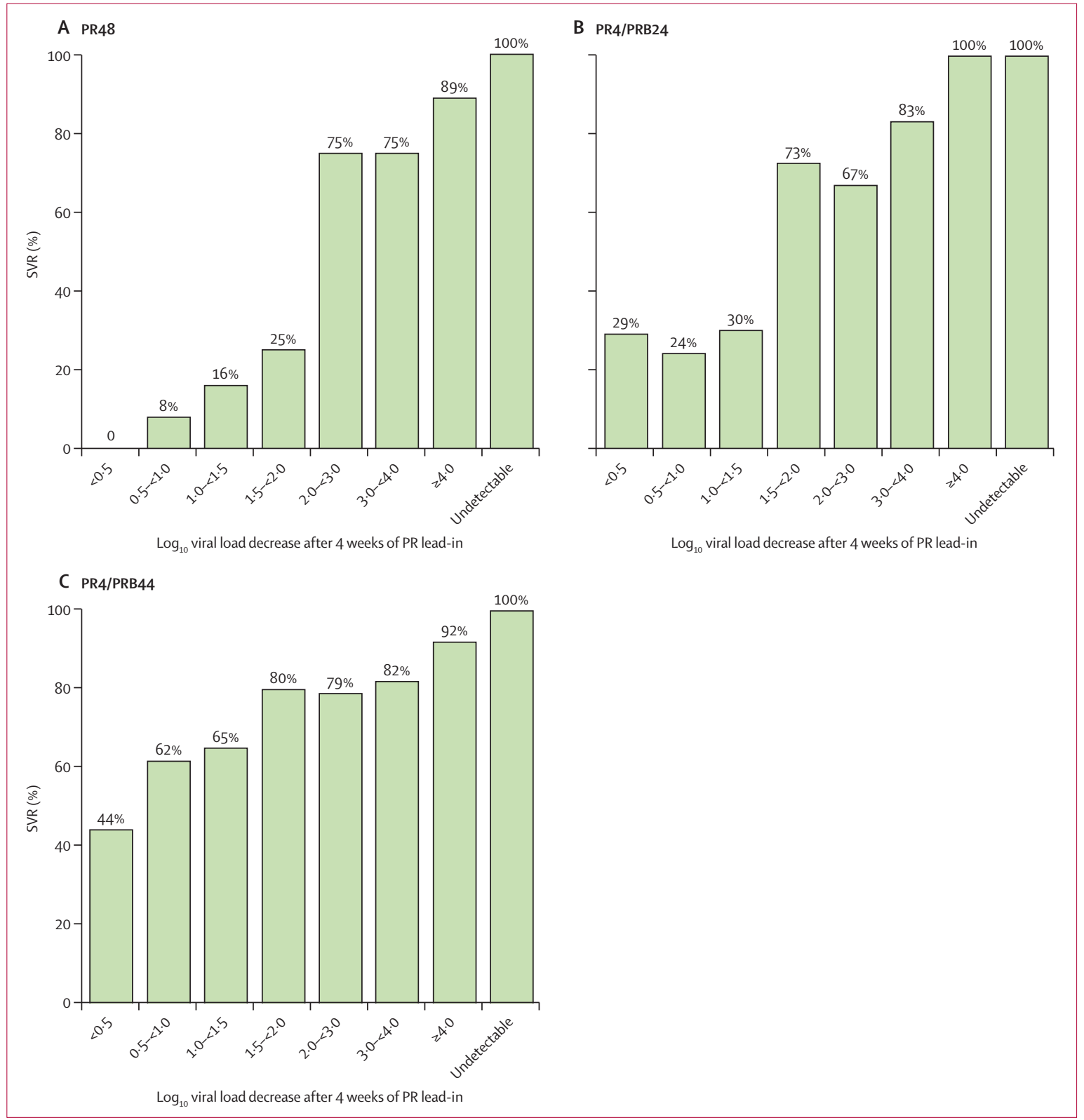

Figure 5: Predictability of sustained virological response (SVR) on the basis of response during 4-week lead-in Undetectable hepatitis C virus RNA with Roche COBASTaqMan with lower limit of detection less than $15 \mathrm{IU} / \mathrm{mL}$. Seven patients in 28-week groups and two in 48 -week groups week missing week-4 virology. PR4 (lead-in)=peginterferon alfa- $2 \mathrm{~b} 1.5 \mathrm{\mu g} / \mathrm{kg}$ plus ribavirin 800-1400 mg per day for 4 weeks. PR48 (control)=peginterferon alfa$2 \mathrm{~b} 1.5 \mathrm{\mu g} / \mathrm{kg}$ plus ribavirin 800-1400 mg per day for 48 weeks. PRB24/44=peginterferon alfa-2b, ribavirin, and boceprevir $800 \mathrm{mg}$ three times a day for 24 or 44 weeks. 
breakthrough, and allowed for potential determination of treatment duration on the basis of responsiveness to the PR4 lead-in. However, in the direct comparison between lead-in and non-lead-in groups, relapse reduction did not differ significantly, although the absence of a statistically conclusive result is not surprising since the sample size did not allow detection of modest differences between lead-in and non-lead-in groups. The mutations recorded in participants with viral breakthrough were consistent what those that have been previously reported with NS3 inhibitors with no new mutations noted. ${ }^{23-26}$ The clinical relevance of these mutations is unknown, and long-term follow-up is in progress.

The viral response during the lead-in could help to predict best possible treatment duration. Patients achieving less than $1.5 \log _{10}$ reduction in viral level after PR4 benefit most from a treatment duration of 48 weeks, whereas those with greater than $1.5 \log _{10}$ reduction show

\begin{tabular}{|c|c|c|c|c|c|c|}
\hline & \multicolumn{5}{|l|}{ Part 1} & \multirow{2}{*}{$\begin{array}{l}\text { OR }(95 \% \mathrm{Cl}) \text { for PR } 4 / \text { PRB44 } \\
\text { vs control (PR48)* }\end{array}$} \\
\hline & $\begin{array}{l}\text { PR48 } \\
(n=104)\end{array}$ & $\begin{array}{l}\text { PR4/PRB24 } \\
(n=103)\end{array}$ & $\begin{array}{l}\text { PR4/PRB44 } \\
(n=103)\end{array}$ & $\begin{array}{l}\text { PRB28 } \\
(n=107)\end{array}$ & $\begin{array}{l}\text { PRB48 } \\
(n=103)\end{array}$ & \\
\hline Overall SVR & $39(38 \%)$ & $58(56 \%)$ & $77(75 \%)$ & $58(54 \%)$ & $69(67 \%)$ & $5 \cdot 4(2 \cdot 9-10 \cdot 0)$ \\
\hline \multicolumn{7}{|l|}{ Sex } \\
\hline Men & $28 / 70(40 \%)$ & $33 / 51(65 \%)$ & $41 / 58(71 \%)$ & $33 / 63(52 \%)$ & $40 / 63(64 \%)$ & $4 \cdot 0(1 \cdot 8-8 \cdot 5)$ \\
\hline Women & $11 / 34(32 \%)$ & $25 / 52(48 \%)$ & $36 / 45(80 \%)$ & $25 / 44(59 \%)$ & $29 / 40(73 \%)$ & $8 \cdot 7(2 \cdot 8-27 \cdot 0)$ \\
\hline \multicolumn{7}{|l|}{ Race $†$} \\
\hline Non-black & $37 / 88(42 \%)$ & $52 / 88(59 \%)$ & $69 / 88(78 \%)$ & $51 / 89(57 \%)$ & $65 / 89(73 \%)$ & $5 \cdot 3(2 \cdot 7-10 \cdot 3)$ \\
\hline Black & $2 / 16(13 \%)$ & $6 / 15(40 \%)$ & $8 / 15(53 \%)$ & $7 / 18(39 \%)$ & $4 / 14(29 \%)$ & $14 \cdot 9(1 \cdot 5-144 \cdot 2)$ \\
\hline \multicolumn{7}{|l|}{ HCV genotype $\neq \S$} \\
\hline $1 \mathrm{a}$ & $16 / 53(30 \%)$ & $27 / 53(51 \%)$ & $43 / 60(72 \%)$ & $34 / 67(51 \%)$ & $32 / 55(58 \%)$ & $7 \cdot 5(3 \cdot 1-18 \cdot 2)$ \\
\hline $1 \mathrm{~b}$ & $17 / 42(41 \%)$ & $22 / 37(60 \%)$ & $29 / 35(83 \%)$ & $21 / 30(70 \%)$ & $30 / 36(83 \%)$ & $6 \cdot 5(2 \cdot 2-19 \cdot 5)$ \\
\hline 1 (no subtype) & $6 / 9(67 \%)$ & $9 / 13(69 \%)$ & $5 / 8(63 \%)$ & $3 / 10(30 \%)$ & $7 / 12(58 \%)$ & $0.9(0 \cdot 1-9 \cdot 3)$ \\
\hline \multicolumn{7}{|l|}{ Liver histology } \\
\hline Cirrhosis & $2 / 8(25 \%)$ & $4 / 7(57 \%)$ & $3 / 6(50 \%)$ & $4 / 7(57 \%)$ & $7 / 9(78 \%)$ & $5 \cdot 0(0 \cdot 3-72 \cdot 8)$ \\
\hline No cirrhosis & $37 / 96(39 \%)$ & $54 / 96(56 \%)$ & $74 / 97(76 \%)$ & $54 / 100(54 \%)$ & $62 / 94(66 \%)$ & $5 \cdot 9(3 \cdot 0-11 \cdot 4)$ \\
\hline \multicolumn{7}{|c|}{ Fasting glucose $(\mathrm{mmol} / \mathrm{L}) \varsigma$} \\
\hline$<5 \cdot 6$ & $28 / 69(41 \%)$ & $41 / 72(57 \%)$ & $53 / 71(75 \%)$ & $39 / 69(57 \%)$ & $44 / 62(71 \%)$ & $4 \cdot 6(2 \cdot 2-9 \cdot 8)$ \\
\hline$\geq 5 \cdot 6$ & $9 / 25(36 \%)$ & $15 / 25(60 \%)$ & $19 / 22(86 \%)$ & $12 / 26(46 \%)$ & $16 / 30(53 \%)$ & $14 \cdot 1(2 \cdot 5-79 \cdot 9)$ \\
\hline \multicolumn{7}{|l|}{ Baseline HCV-RNA ${ }^{\dagger}$} \\
\hline$>600000 \mathrm{IU} / \mathrm{mL}$ & $30 / 93(32 \%)$ & $48 / 89(54 \%)$ & $67 / 92(73 \%)$ & $52 / 99(53 \%)$ & $63 / 94(67 \%)$ & $6 \cdot 2(3.2-12 \cdot 1)$ \\
\hline$\leq 600000 \mathrm{IU} / \mathrm{mL}$ & 9/11 (89\%) & $10 / 14(71 \%)$ & $10 / 11(91 \%)$ & $6 / 8(75 \%)$ & $6 / 9(67 \%)$ & $2 \cdot 7(0 \cdot 2-42 \cdot 7)$ \\
\hline \multicolumn{7}{|c|}{ Baseline platelet count $(\times 1000)+\$ \pi$} \\
\hline$<169 \cdot 5$ & $5 / 19(26 \%)$ & $4 / 11(36 \%)$ & $9 / 15(60 \%)$ & $7 / 15(47 \%)$ & $12 / 16(75 \%)$ & $32 / 57(56 \%) \|$ \\
\hline $169 \cdot 5-<237 \cdot 4$ & $14 / 44(32 \%)$ & $25 / 42(60 \%)$ & $33 / 41(80 \%)$ & $32 / 49(65 \%)$ & $26 / 38(68 \%)$ & $116 / 170(68 \%) \|$ \\
\hline $237 \cdot 4-<305 \cdot 4$ & $12 / 26(46 \%)$ & $23 / 33(70 \%)$ & $28 / 33(85 \%)$ & $12 / 27(44 \%)$ & $22 / 34(65 \%)$ & $85 / 127(67 \%) \|$ \\
\hline$\geq 305 \cdot 4$ & $8 / 15(53 \%)$ & $6 / 17(35 \%)$ & $7 / 14(50 \%)$ & $7 / 16(44 \%)$ & $9 / 15(60 \%)$ & $29 / 62(47 \%) \|$ \\
\hline \multicolumn{7}{|c|}{ Nadir haemoglobin ( $\mathrm{g} / \mathrm{L}$ ) } \\
\hline$\geq 100$ & $27 / 78(35 \%)$ & $24 / 51(47 \%)$ & $35 / 55(64 \%)$ & $23 / 49(47 \%)$ & $31 / 55(56 \%)$ & .. \\
\hline$<100$ & $12 / 25(48 \%)$ & $34 / 51(67 \%)$ & $42 / 48(88 \%)$ & $35 / 57(61 \%)$ & $38 / 48(79 \%)$ & .. \\
\hline \multicolumn{7}{|l|}{ Epoetin alfa use } \\
\hline Yes & $9 / 27(33 \%)$ & $33 / 50(66 \%)$ & $46 / 53(87 \%)$ & $27 / 48(56 \%)$ & $32 / 40(80 \%)$ & .. \\
\hline No & 30/77 (39\%) & $25 / 53(47 \%)$ & $31 / 50(62 \%)$ & $31 / 59(53 \%)$ & $37 / 63(59 \%)$ &. \\
\hline \multicolumn{7}{|c|}{ 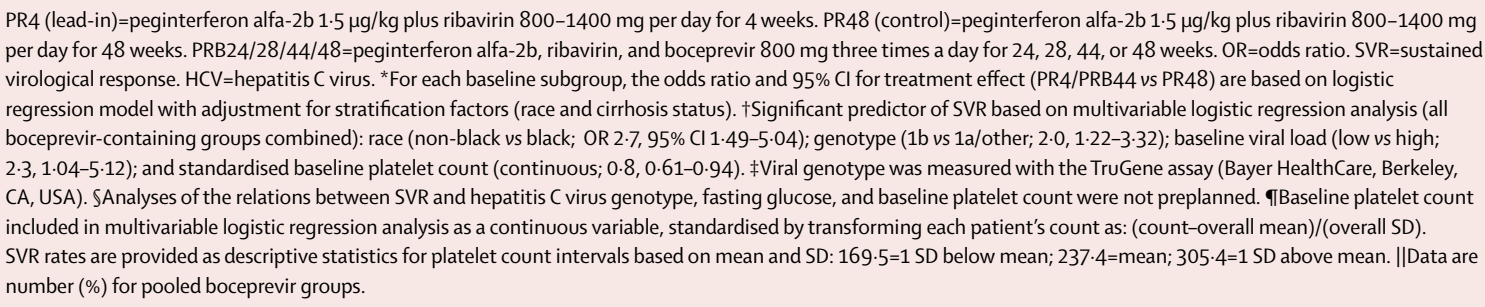 } \\
\hline
\end{tabular}


similar SVR irrespective of treatment duration of 28 weeks or 48 weeks. The lead-in can identify null responders to peginterferon alfa- $2 \mathrm{~b}$ and ribavirin, who

\begin{tabular}{|c|c|c|c|c|c|c|c|}
\hline & \multicolumn{5}{|l|}{ Part 1} & \multicolumn{2}{|l|}{ Part 2} \\
\hline & $\begin{array}{l}\text { PR48 } \\
(n=104)\end{array}$ & $\begin{array}{l}\text { PR4/PRB24 } \\
(n=103)\end{array}$ & $\begin{array}{l}\text { PR4/PRB44 } \\
(n=103)\end{array}$ & $\begin{array}{l}\text { PRB28 } \\
(n=107)\end{array}$ & $\begin{array}{l}\text { PRB48 } \\
(n=103)\end{array}$ & $\begin{array}{l}\text { PRB48 } \\
(n=16)\end{array}$ & $\begin{array}{l}\text { Low-dose } \\
\text { PRB48 } \\
(n=59)\end{array}$ \\
\hline Fatigue & $57(55 \%)$ & $70(68 \%)$ & $73(71 \%)$ & $65(61 \%)$ & $51(50 \%)$ & $11(69 \%)$ & $40(68 \%)$ \\
\hline Anaemia & $35(34 \%)$ & $55(53 \%)$ & $58(56 \%)$ & $60(56 \%)$ & $54(52 \%)$ & $10(63 \%)$ & $14(24 \%)$ \\
\hline Headache & $45(43 \%)$ & $41(40 \%)$ & $54(52 \%)$ & $52(49 \%)$ & $44(43 \%)$ & $13(81 \%)$ & $29(49 \%)$ \\
\hline Nausea & $45(43 \%)$ & $42(41 \%)$ & $48(47 \%)$ & $41(38 \%)$ & $56(54 \%)$ & $10(63 \%)$ & $35(59 \%)$ \\
\hline Insomnia & $40(38 \%)$ & $29(28 \%)$ & $41(40 \%)$ & $36(34 \%)$ & $40(39 \%)$ & $7(44 \%)$ & $23(39 \%)$ \\
\hline Pyrexia & $35(34 \%)$ & $27(26 \%)$ & $35(34 \%)$ & $28(26 \%)$ & $41(40 \%)$ & $7(44 \%)$ & $26(44 \%)$ \\
\hline Chills & $35(34 \%)$ & $31(30 \%)$ & $35(34 \%)$ & $31(29 \%)$ & $33(32 \%)$ & $5(31 \%)$ & $26(44 \%)$ \\
\hline Alopecia & $27(26 \%)$ & $30(29 \%)$ & $35(34 \%)$ & $36(34 \%)$ & $30(29 \%)$ & $5(31 \%)$ & $19(32 \%)$ \\
\hline Diarrhoea & $23(22 \%)$ & $27(26 \%)$ & $29(28 \%)$ & $28(26 \%)$ & $25(24 \%)$ & $5(31 \%)$ & $14(24 \%)$ \\
\hline Dysgeusia & $9(9 \%)$ & $27(26 \%)$ & $28(27 \%)$ & $23(21 \%)$ & $33(32 \%)$ & $7(44 \%)$ & $18(31 \%)$ \\
\hline Neutropenia & $12(12 \%)$ & $17(17 \%)$ & $31(30 \%)$ & $25(23 \%)$ & $26(25 \%)$ & $3(19 \%)$ & $19(32 \%)$ \\
\hline Influenza-like illness & $25(24 \%)$ & $21(20 \%)$ & $15(15 \%)$ & $24(22 \%)$ & $19(18 \%)$ & $6(38 \%)$ & $11(19 \%)$ \\
\hline Arthralgia & $21(20 \%)$ & $22(21 \%)$ & $19(18 \%)$ & $14(13 \%)$ & $21(20 \%)$ & $5(31 \%)$ & $11(19 \%)$ \\
\hline Dizziness & $16(15 \%)$ & $16(16 \%)$ & $14(14 \%)$ & $19(18 \%)$ & $21(20 \%)$ & $7(44 \%)$ & $11(19 \%)$ \\
\hline Vomiting & $5(5 \%)$ & $15(15 \%)$ & $17(17 \%)$ & $24(22 \%)$ & $25(24 \%)$ & $7(44 \%)$ & $11(19 \%)$ \\
\hline Decreased appetite & $12(12 \%)$ & $14(14 \%)$ & $12(12 \%)$ & $7(7 \%)$ & $17(17 \%)$ & $6(38 \%)$ & $16(27 \%)$ \\
\hline Injection-site reaction & $10(10 \%)$ & $5(5 \%)$ & $11(11 \%)$ & $9(8 \%)$ & $9(9 \%)$ & $4(25 \%)$ & $21(36 \%)$ \\
\hline
\end{tabular}

Data are number (\%). Adverse events as assessed and reported by investigator are presented in decreasing frequency on the basis of the counts for all treatments combined. PR4 (lead-in)=peginterferon alfa-2b $1.5 \mu \mathrm{g} / \mathrm{kg}$ plus ribavirin 800-1400 mg per day for 4 weeks. PR48 (control)=peginterferon alfa- $2 \mathrm{~b} 1.5 \mu \mathrm{g} / \mathrm{kg}$ plus ribavirin $800-1400 \mathrm{mg}$ per day for 48 weeks. PRB24/28/44/48=peginterferon alfa-2b, ribavirin, and boceprevir $800 \mathrm{mg}$ three times a day for $24,28,44$, or 48 weeks. Low-dose PRB48=peginterferon alfa-2b, ribavirin $400-1000 \mathrm{mg}$, and boceprevir $800 \mathrm{mg}$ three times a day for 48 weeks.

Table 5: Adverse events during treatment ( $\geq 30 \%$ incidence)

\begin{tabular}{|c|c|c|c|c|c|c|c|}
\hline & \multicolumn{5}{|l|}{ Part 1} & \multicolumn{2}{|l|}{ Part 2} \\
\hline & $\begin{array}{l}\text { PR48 } \\
(n=104)\end{array}$ & $\begin{array}{l}\text { PR4/PRB24 } \\
(n=103)\end{array}$ & $\begin{array}{l}\text { PR4/PRB44 } \\
(n=103)\end{array}$ & $\begin{array}{l}\text { PRB28 } \\
(n=107)\end{array}$ & $\begin{array}{l}\text { PRB48 } \\
(n=103)\end{array}$ & $\begin{array}{l}\text { PRB48 } \\
(n=16)\end{array}$ & $\begin{array}{l}\text { Low-dose } \\
\text { PRB48 }(n=59)\end{array}$ \\
\hline \multicolumn{8}{|c|}{ Neutrophils (cells per $\mu \mathrm{L}$ ) } \\
\hline $500-<750$ & $15(15 \%)$ & $13(13 \%)$ & $22(21 \%)$ & $22(21 \%)$ & $33(32 \%)$ & 0 & $12(20 \%)$ \\
\hline$<500$ & $3(3 \%)$ & $8(8 \%)$ & $15(15 \%)$ & $14(13 \%)$ & $5(5 \%)$ & $2(14 \%)$ & 0 \\
\hline \multicolumn{8}{|l|}{ Haemoglobin (g/L) } \\
\hline $85-<100$ & $25(24 \%)$ & $50(49 \%)$ & $43(42 \%)$ & $52(49 \%)$ & $45(44 \%)$ & $7(50 \%)$ & $12(20 \%)$ \\
\hline$<85$ & 0 & $1(1 \%)$ & $5(5 \%)$ & $5(5 \%)$ & $3(3 \%)$ & $2(14 \%)$ & 0 \\
\hline Epoetin alfa use & $53(51 \%)$ & $50(49 \%)$ & $40(39 \%)$ & $27(26 \%)$ & $48(45 \%)$ & $9(56 \%)$ & $9(15 \%)$ \\
\hline pRBC transfusion & 0 & $1(1 \%)$ & 0 & 0 & 0 & 0 & $1(<1 \%)$ \\
\hline \multicolumn{8}{|l|}{ Platelets $\left(\times 10^{9} / \mathrm{L}\right)$} \\
\hline $25-<50$ & 0 & $2(2 \%)$ & $3(3 \%)$ & $4(4 \%)$ & $1(1 \%)$ & 0 & $1(2 \%)$ \\
\hline$<25$ & 0 & 0 & $1(1 \%)$ & 0 & 0 & 0 & 0 \\
\hline \multicolumn{8}{|c|}{$\begin{array}{l}\text { Data are number (\%). Haematological parameters during therapy are reported. Reduction of dose of peginterferon was } \\
\text { recommended if neutrophil count was less than } 0.75 \times 109 / \mathrm{L} \text { and } / \text { or platelet count was less than } 50 \times 109 / \mathrm{L} \text {; } \\
\text { discontinuation of peginterferon was recommended if neutrophil count was less than } 0.5 \times 10^{9} / \mathrm{L} \text { and } / \text { or platelet count } \\
\text { was less than } 25 \times 109 / \mathrm{L} \text {. Reduction of ribavirin dose was recommended if haemoglobin was less than } 100 \mathrm{~g} / \mathrm{L} \text {, and } \\
\text { discontinuation or interruption of ribavirin occurred if haemoglobin was less than } 85 \mathrm{~g} / \mathrm{L} \text {. PR4 (lead-in)=peginterferon } \\
\text { alfa- } 2 \mathrm{~b} 1.5 \mu \mathrm{g} / \mathrm{kg} \text { plus ribavirin } 800-1400 \mathrm{mg} \text { per day for } 4 \text { weeks. PR48 (control)=peginterferon alfa- } 2 \mathrm{~b} 1 \cdot 5 \mu \mathrm{g} / \mathrm{kg} \\
\text { plus ribavirin } 800-1400 \mathrm{mg} \text { per day for } 48 \text { weeks. PRB } 24 / 28 / 44 / 48=\text { peginterferon alfa- } 2 \mathrm{~b} \text {, ribavirin, and boceprevir } \\
800 \mathrm{mg} \text { three times a day for } 24,28,44 \text {, or } 48 \text { weeks. Low-dose PRB48=peginterferon alfa- } 2 \mathrm{~b} \text {, ribavirin } \\
400-1000 \mathrm{mg} \text {, and boceprevir } 800 \mathrm{mg} \text { three times a day for } 48 \text { weeks. pRBC=packed red blood cells. }\end{array}$} \\
\hline
\end{tabular}

seem to be at greatest risk for treatment failure with specifically targeted therapies and for development of resistance. However, in our cohort, a substantial proportion of null responders during the lead-in period went on to achieve SVR with the addition of boceprevir. ${ }^{16,27}$

In all groups, rapid virological response was highly predictive of SVR. We also recorded high rates of rapid virological response in the 48-week treatment groups. Participants who cleared virus between weeks 4 and 12 of boceprevir therapy were more likely to go on to SVR if they received 48 weeks of treatment rather than 28 weeks. Thus, in the treatment of genotype 1 hepatitis $\mathrm{C}$ virus, nearly two-thirds of patients achieved undetectable hepatitis C virus RNA levels at week 4 of boceprevir therapy after PR4, and these individuals can be treated for 28 weeks with high SVR. Of the additional 18\% (19/103) of patients who go on to achieve undetectable hepatitis C virus RNA between weeks 4 and 12 of boceprevir therapy, $79 \%(15 / 19)$ of patients benefit from extending therapy with peginterferon alfa- $2 \mathrm{~b}$, ribavirin, and boceprevir to 48 weeks. Only one patient in the boceprevir groups who developed undetectable hepatitis C virus RNA after week 12 of boceprevir therapy went on to SVR.

We noted no new adverse events or treatment-limiting toxic effects associated with boceprevir-containing regimens in this trial compared with those recorded in patients receiving peginterferon and ribavirin. No increases in skin or subcutaneous adverse events were noted in the boceprevir-containing groups compared with the control groups. Higher rates of both anaemia and dysgeusia were noted in the boceprevir-containing regimens than in the control group, although stopping treatment for anaemia was rare. Haemoglobin reductions in the PRB48 low-dose group were less than those in the control group and in any of the full-dose PRB groups in part 1 , and similar to the haemoglobin reduction in the PR48 group of part 1 of the study. In this study, use of epoetin alfa was allowed at the investigator's discretion and was associated with improved SVR. A study suggested that development of anaemia with haemoglobin less than $100 \mathrm{~g} / \mathrm{L}$ is associated with increased SVR in patients receiving pegylated interferon and ribavirin; anaemia is potentially a surrogate marker of increased ribavirin concentration and the addition of epoetin alfa might allow patients to remain on therapy. ${ }^{28}$ In our study, the development of anaemia and the use of epoetin alfa were associated with improved SVR in the boceprevir-containing regimens. However, since there was no randomisation for use of epoetin alfa in this study, the contributions of anaemia and epoetin alfa use to improved SVR with boceprevir remains to be established. The role of epoetin alfa as an adjuvant in patients receiving pegylated interferon and ribavirin in addition to therapy with directacting antiviral agents deserves further study. We recorded a higher drop-out rate in the boceprevir-containing groups than in the control group, as has been noted when other direct-acting antiviral agents are added to peginterferon 


\begin{tabular}{|c|c|c|c|c|c|c|c|}
\hline & \multicolumn{5}{|l|}{ Part 1} & \multicolumn{2}{|l|}{ Part 2} \\
\hline & $\begin{array}{l}\text { PR48 } \\
(n=104)\end{array}$ & $\begin{array}{l}\text { PR4/PRB24 } \\
(n=103)\end{array}$ & $\begin{array}{l}\text { PR4/PRB44 } \\
(n=103)\end{array}$ & $\begin{array}{l}\text { PRB28 } \\
(n=107)\end{array}$ & $\begin{array}{l}\text { PRB48 } \\
(n=103)\end{array}$ & $\begin{array}{l}\text { PRB48 } \\
(n=16)\end{array}$ & $\begin{array}{l}\text { Low-dose PRB48 } \\
(n=59)\end{array}$ \\
\hline Overall discontinuations & $16(15 \%)$ & $27(26 \%)$ & $27(26 \%)$ & $30(28 \%)$ & $40(39 \%)$ & $8(50 \%)$ & $31(53 \%)$ \\
\hline p value compared with PR48 (control) & .. & 0.055 & 0.055 & 0.026 & 0.0001 &.. &.. \\
\hline \multicolumn{8}{|l|}{ Reason for discontinuation } \\
\hline Adverse event & $8(8 \%)$ & $15(15 \%)$ & $9(9 \%)$ & $12(11 \%)$ & $20(19 \%)$ & $4(25 \%)$ & $7(12 \%)$ \\
\hline Serious adverse event & $3(3 \%)$ & $6(6 \%)$ & $3(3 \%)$ & $6(6 \%)$ & $9(9 \%)$ & $1(6 \%)$ & 0 \\
\hline Anaemia $^{*}$ & 0 & 1 & 0 & 0 & 0 & 1 & 0 \\
\hline \multicolumn{8}{|l|}{ Dose reductions due to adverse events } \\
\hline All & $30(29 \%)$ & $57(55 \%)$ & $66(64 \%)$ & $56(52 \%)$ & $58(56 \%)$ & $8(50 \%)$ & $15(25 \%)$ \\
\hline Reductions of peginterferon and/or ribavirin only $\dagger$ & $30(29 \%)$ & $49(48 \%)$ & $50(49 \%)$ & $46(43 \%)$ & $41(40 \%)$ & $8(50 \%)$ & $14(24 \%)$ \\
\hline Reductions due to boceprevir $¥$ & 0 & $8(8 \%)$ & $16(16 \%)$ & $10(9 \%)$ & $17(17 \%)$ & 0 & $1(2 \%)$ \\
\hline \multicolumn{8}{|c|}{ 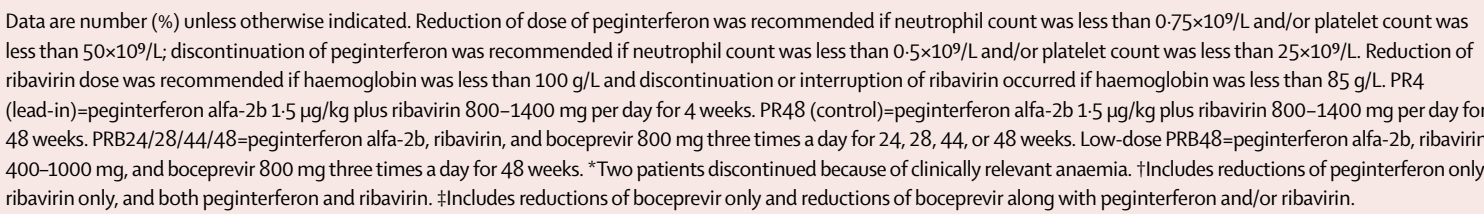 } \\
\hline
\end{tabular}

alfa- $2 \mathrm{~b}$ and ribavirin. ${ }^{17}$ This findings suggests that treating physicians might need experience with these agents to ensure patient adherence and manage side-effects, as was noted with the introduction of ribavirin to interferon therapy for hepatitis $\mathrm{C}$ virus infection. ${ }^{17,18}$

There are potential limitations of this study which deserve mention. This was an open-label study with regard to the administration of boceprevir because of the complex study design with comparisons of lead-in and non-lead-in groups, and differing treatment durations. However, all assays were done by an independent commercial laboratory that did not have access to participant treatment assignments. The primary and other key study endpoints were based on hepatitis C virus RNA level-an outcome that is not subject to bias. Another possible limitation concerns the stratification of patients as with or without cirrhosis. We required a liver biopsy sample to be taken within 5 years of enrolment into the study. A patient who tested negative for cirrhosis 5 years before the beginning of the study could have developed cirrhosis in the intervening years. Thus patients with cirrhosis could have been mischaracterised as being non-cirrhotic, biasing the results in favour of the population with this disease. Therefore, the promising results obtained in patients with cirrhosis who received boceprevir will need confirmation in larger trials that are in progress.

In conclusion, boceprevir, in combination with pegylated interferon and ribavirin, achieved high SVR rates with 28 weeks of therapy in most patients and is safe and effective for use up to 48 weeks in the few patients who benefit from longer duration of therapy. We also recorded increased response rates in difficult-to-treat groups, including black participants and those with cirrhosis. The use of PR4 lead-in before the addition of boceprevir improves SVR over a 48-week duration, and reduces viral breakthrough and relapse. A large confirmatory trial is in progress and will define the best treatment regimen for the use of boceprevir in the treatment of genotype 1 chronic hepatitis $\mathrm{C}$ virus infection.

Contributors

PYK, EJL, JSG, ERS, MND, SCG, LR, JMCC, DP, IMJ, LDP, CAB, EC, JKA, JMV, NR, RR, and KK contributed to the writing and review of the report. PYK, EJL, JSG, ERS, MND, SCG, LR, JMV, NR, and RR contributed to patient recruitment. PYK, EJL, JSG, ERS, MND, SCG, LR, JMcC, DP, IMJ, JMV, NR, and FHA served as investigators in this study. EJL, JSG, EC, JKA, JMV, NR, and RR contributed to the data collection. LDP, CAB, EC, JKA, JMV, and KK contributed to the study design. LDP, $\mathrm{CAB}, \mathrm{EC}, \mathrm{JKA}, \mathrm{JMV}, \mathrm{NR}$, and RR contributed to trial management. EC, JKA, and KK contributed to the statistical analyses of the study. PYK served as the principal investigator for this study and presented the data.

\section{Participating members of the SPRINT-1 study group}

M Adler, F Anderson, L Balart, R Barcena Marugan, T Berg, M Bourliere, T Boyer, J P Bronowicki, R Brown, G Carosi, W Cassidy, R Chung, A Craxi, G Davis, M Davis, R Esteban-Mur, S Flamm, X Forns, B Freilich, J Galati, G Galler, R Ghalib, A Gibas, E Godofsky, S Gordon, J Heathcote, J Herrera, C Hezode, I Jacobson, S Joshi, J King, P Kwo, E Lawitz, W Lee, J Levin, M Manns, P Marcellin, P Marotta, J McCone, T Morgan, F Nevens, C Niederau, F Nunes, L Nyberg, M P Pauly, C Peine, G D Poleynard, F Poordad, D Pound, T Poynard, N Ravendhran, H W Reesink, J Reichen, M Rizzetto, L Rossaro, R Rubin, M Ryan, E Schiff, S Shafran, K Sherman, M Shiffman, C Smith, R Strauss, M Sulkowski, C Trepo, J Vierling, Z Younes, S Zeuzem.

\section{Conflicts of interest}

PYK has received research grants, honoraria, consultancy fees, and travel grants from Schering-Plough/Merck; research grants from Vertex,

Tibotec, Roche, Abbott, Bristol-Myers Squibb, Gilead, Idenix, Valeant, GlaxoSmithKline, and Human Genome Sciences; served on advisory boards for Vertex, Gilead, Anadys, Abbott, Human Genome Sciences, and Novartis; and is on the speaker's bureau for Schering Plough/Merck, Roche, Gilead, and Bristol-Myers Squibb. JMV has received research grants from Abbott, Conatus, Excalenz, Gilead, GlobeImmune, Hyperion, Idenix-Novartis, Intercept, Merck/Schering-Plough, Novartis, Ocera, Pharmasset, Pfizer, Sundise, Vertex, and ZymoGenetics; and is on the speakers' bureau for Bristol-Myers Squibb, Chronic Liver Disease 
Foundation, Gilead, Roche, and Merck. EJL has received research grants from Abbott, Anadys, Biolex, Bristol-Myers Squibb, Gilead, GlaxoSmithKline, GlobeImmune, Human Genome Sciences, Idenix, Idera, Intarcia, Medarex, Medtronic, Merck, Novartis, Pharmasset, Roche, Schering-Plough, Tibotec, Valeant, Vertex, ViroChem Pharma, and ZymoGenetics; and honoraria from Merck. ERS has received honoraria (speaking and advisory boards) and research grants from Abbott, Anadys, Bristol-Myers Squibb, Gilead, GlobeImmune, Merck, Medtronics, Roche Diagnostics, Roche Molecular, Salix, Sanofi-Aventis, Schering-Plough, SciClone, and Vertex; and has served on advisory boards for BristolMyers Squibb, Gilead, Johnson \& Johnson, Merck, Orasure, and Roche Molecular. SCG has received research support and grants from Abbott, Anadys, Biolex, Bristol-Myers Squibb, Exalenz, Gilead, GlaxoSmithKline GlobeImmune, Human Genome Science, Merck, Roche, ScheringPlough, SciClone, Tibotec, Vertex, ViroChem Pharma, and ZymoGenetics; is on the speakers' bureau for Gilead, Merck, and Roche; and has received consultancy fees from Dynavax, Gilead, and Merck. MND is on the speakers' bureau of Genentech and Merck, a member of the Roche group; and has received research grants from Schering-Plough and Vertex. NR has received research grants from Schering-Plough. FHA has received research grants from Bristol-Myers Squibb, Gilead, Novartis, Roche, Schering-Plough, ZymoGenetics, Debiopharm, and Pharmasset; has served as an advisor for Bristol-Myers Squibb, Gilead, and ScheringPlough; and has received gifts from Merck and Roche (for nursing support). RR has received research support and honoraria from Schering Plough, Roche, Vertex, Gilead, Conatus, and Bristol-Myers Squibb. IMJ has received research support and grants from Schering-Plough, Valeant, Gilead, Vertex, GlobeImmune, Human Genome Sciences, Novartis, Boehringer Ingelheim, Anadys, Pharmasset, Roche, Merck, Tibotec, and Romark; consultancy fees from Bristol-Myers Squibb, Novartis, Gilead, Schering-Plough, Pfizer, Vertex, GlobeImmune, Human Genome Sciences, Merck, Boehringer Ingelheim, Pharmasset, ZymoGenetics, Tibotec, Abbott, Roche, Anadys, and Progenics; and is on the speakers' bureau for Roche and Schering-Plough, Gilead, Bristol-Myers Squibb, and Novartis. LR has received grants from and has given lectures for Genentec, Merck, Vertex, Novartis, and Three Rivers; has received honoraria from Genentec, Merck, Vertex, and Three Rivers; and is on the speakers' bureau for Genentech, Schering-Plough, and Three Rivers. $\mathrm{JMcC}$ is on the speakers' bureau for Roche and Schering-Plough. KK, LDP, EC, JKA, and CAB are employees and stockholders of Merck. DP has received research support and grants from Schering-Plough and was on the speakers' bureau for Schering-Plough. JSG has received research support and grants from Schering-Plough.

\section{Acknowledgments}

We thank the patients for their participation and support during this trial; and David McNeel and Holli Brousseau (medical writers, Sui Generis Health New York, NY, USA) for their assistance with report preparation (funded by Schering, a Division of Merck).

\section{References}

1 Verna EC, Brown RS, Jr. Hepatitis C virus and liver transplantation. Clin Liver Dis 2006; 10: 919-40.

2 Lauer GM, Walker BD. Hepatitis C virus infection. N Engl J Med 2001; 345: 41-52.

3 McHutchison JG, Lawitz EJ, Shiffman ML, et al. Peginterferon ab or alfa-2a with ribavirin for treatment of hepatitis $\mathrm{C}$ infection. $N$ Engl J Med 2009; 361: 580-93.

4 Manns MP, McHutchison JG, Gordon SC, et al, for the International Hepatitis Interventional Therapy Group. Peginterferon alfa-2b plus ribavirin compared with interferon $\mathrm{ab}$ plus ribavirin for initial treatment of chronic hepatitis C: a randomised trial. Lancet 2001; 358: 958-65.

5 Fried MW, Shiffman ML, Reddy KR, et al. Peginterferon alfa-2a plus ribavirin for chronic hepatitis C virus infection. N Engl J Med 2002; 347: 975-82.

6 Muir AJ, Bornstein JD, Killenberg PG, Atlantic Coast Hepatitis Treatment Group. Peginterferon alfa- $2 \mathrm{~b}$ and ribavirin for the treatment of chronic hepatitis $\mathrm{C}$ in blacks and non-Hispanic whites. $N$ Engl J Med 2004; 350: 2265-71.

7 Conjeevaram HS, Fried MW, Jeffers LJ, et al. Peginterferon and ribavirin treatment in African American and Caucasian American patients with hepatitis C genotype 1. Gastroenterology 2006; 131: 470-77.
8 Poynard T, McHutchison JG, Manns MP, et al. Impact of pegylated interferon alfa- $2 \mathrm{~b}$ and ribavirin on liver fibrosis in patients with chronic hepatitis C. Gastroenterology 2002; 122: 1303-13.

9 Davis GL, Wong JB, McHutchison JG, Manns MP, Harvey J, Albrecht J. Early virologic response to treatment with peginterferon alfa-2b plus ribavirin in patients with chronic hepatitis $C$ Hepatology 2003; 38: 645-52.

10 Ferenci P, Fried MW, Shiffman ML, et al. Predicting sustained virological responses in chronic hepatitis $C$ patients treated with peginterferon alfa-2a (40 KD)/ribavirin. J Hepatol 2005; 43: 425-33.

11 Jensen DM, Morgan TR, Marcellin P, et al. Early identification of HCV genotype 1 patients responding to 24 weeks peginterferon alpha-2a (40 kd)/ribavirin therapy. Hepatology 2006; 43: 954-60.

12 Zeuzem S, Buti M, Ferenci P, et al. Efficacy of 24 weeks treatment with peginterferon alfa- $2 \mathrm{~b}$ plus ribavirin in patients with chronic hepatitis $\mathrm{C}$ infected with genotype 1 and low pretreatment viremia. J Hepatol 2006; 44: 97-103.

13 McGovern BH, Abu Dayyeh BK, Chung RT. Avoiding therapeutic pitfalls: the rational use of specifically targeted agents against hepatitis C infection. Hepatology 2008; 48: 1700-12.

14 Malcolm BA, Liu R, Lahser F, et al. SCH 503034, a mechanismbased inhibitor of hepatitis $\mathrm{C}$ virus NS3 protease, suppresses polyprotein maturation and enhances the antiviral activity of alpha interferon in replicon cells. Antimicrob Agents Chemother 2006; 50: 1013-20.

15 Sarrazin C, Rouzier R, Wagner F, et al. SCH 503034, a novel hepatitis $C$ virus protease inhibitor, plus pegylated interferon alpha-2b for genotype 1 nonresponders. Gastroenterology 2007; 132: $1270-78$.

16 Schiff E, Poordad E, Jacobson I, et al. Boceprevir (B) combination therapy in null responders (NR): response dependent on interferon responsiveness. J Hepatol 2008; 48: S46S.

17 McHutchison JG, Everson GT, Gordon SC, et al. Telaprevir with peginterferon and ribavirin for chronic HCV genotype 1 infection. N Engl J Med 2009; 360: 1827-38.

18 Hézode C, Forestier N, Dusheiko G, et al. Telaprevir and peginterferon with or without ribavirin for chronic $\mathrm{HCV}$ infection. N Engl J Med 2009; 360: 1839-50.

19 Kwo P, Lawitz E, McCone K, et al. Response-guided therapy (RGT) for boceprevir (BOC) combination treatment? Results from HCV SPRINT-1. Hepatology 2009; 50 (suppl 4): 1035A-36A (abstr).

20 Kwo P, Lawitz E, McCone J, et al. High sustained virologic response (SVR) in genotype 1 (G1) null responders to peg-interferon alfa- $2 \mathrm{~b}$ (P) plus ribavirin (R) when treated with boceprevir (BOC) combination therapy. Hepatology 2009; 50 (suppl 4): 331A-32A (abstr).

21 Berman K, Kwo PY. Boceprevir, an NS3 protease inhibitor of HCV. Clin Liver Dis 2009; 13: 429-39.

22 Wood L, Egger M, Gluud LL, et al. Empirical evidence of bias in treatment effect estimates in controlled trials with differen interventions and outcomes: meta-epidemiological study. BMJ 2008; 336: 601-05.

23 Susser S, Welsch C, Wang Y, et al. Characterization of resistance to the protease inhibitor boceprevir in hepatitis $\mathrm{C}$ virus-infected patients. Hepatology 2009; 50: 1709-18.

24 Sarrazin C, Kieffer TL, Bartels D, et al. Dynamic hepatitis C virus genotypic and phenotypic changes in patients treated with the protease inhibitor telaprevir. Gastroenterology 2007; 132: 1767-77.

25 Tong X, Chase R, Skelton A, Chen T, Wright-Minogue J, Malcolm BA. Identification and analysis of fitness of resistance mutations against the HCV protease inhibitor SCH 503034. Antiviral Res 2006; 70: 28-38.

26 Tong X, Bogen S, Chase R, et al. Characterization of resistance mutations against HCV ketoamide protease inhibitors. Antiviral Res 2008; 77: 177-85.

27 Curry S, Qiu P, Tong X. Analysis of HCV resistance mutations during combination therapy with protease inhibitor boceprevir and PEG-IFN alpha-2b using TaqMan mismatch amplification mutation assay. J Virol Methods 2008; 153: 156-62.

28 Sulkowski M, Shiffman M, Afdhal N, et al. Hemoglobin decline is associated with SVR among HCV genotype 1-infected persons treated with peginterferon (PEG)/ribavirin (RBV): analysis from the ideal study. J Hepatol 2009; 50: s51. 